\title{
Distribution of Pesticide Residues in Rice Grain and in its Coproducts
}

\author{
Giniani C. Dors, ${ }^{*, a}$ Ednei G. Primel, ${ }^{b}$ Carlos A. A. Fagundes, ${ }^{c}$ Carlos H. P. Mariot ${ }^{c}$ and \\ Eliana Badiale-Furlong ${ }^{a}$
}

\author{
${ }^{a}$ Laboratório de Ciências de Alimentos, Escola de Química e Alimentos, Universidade Federal do \\ Rio Grande, Rua Eng. Alfredo Huch, 475, Centro, CP 474, 96201-900 Rio Grande-RS, Brazil \\ ${ }^{b}$ Laboratório de Análises de Compostos Orgânicos e Metais, Universidade Federal do Rio Grande, \\ Avenida Itália, km 8, Campus Carreiros, 96208-410 Rio Grande-RS, Brazil
}

'Instituto Rio Grandense do Arroz, Av. Bonifácio Carvalho Bernardes, 1494, 94930-030 Cachoeirinha-RS, Brazil

\begin{abstract}
Os agrotóxicos são usados em muitas culturas para prevenir e preservar os grãos de possíveis ataques de pragas. O objetivo deste trabalho foi avaliar a distribuição dos agrotóxicos bispiribaque de sódio, carbofurano, clomazona e tebuconazol nas diferentes frações do arroz beneficiado (arroz branco, farelo de arroz, arroz com casca, arroz parboilizado beneficiado, farelo de arroz parboilizado e arroz parboilizado com casca), o qual foi cultivado em campos experimentais sob condições controladas de aplicação. Para tanto, o método QuEChERS foi otimizado para a extração dos agrotóxicos e validou-se um método utilizando CLAE-DAD para quantificação e CL-EM para confirmação. O método QuEChERS modificado foi adequado na extração dos agrotóxicos, bem como as condições cromatográficas para identificação e quantificação, conforme os indicativos de eficiência determinados: LOD de $0,07 \mathrm{mg} \mathrm{kg}^{-1}$ e LOQ de $0,2 \mathrm{mg} \mathrm{kg}^{-1}$ para a mistura dos agrotóxicos, e recuperação para arroz e farelo de arroz de 119 e 116\%, 84 e 119\%, 113 e 96\%, 103 e $97 \%$ para carbofurano, bispiribaque de sódio, clomazona e tebuconazol, respectivamente. O método desenvolvido foi aplicado nas frações do beneficiamento e o farelo apresentou maior concentração de resíduo dos agrotóxicos, quando comparado ao arroz beneficiado, sendo 8,0, 2,3, 2,2 e 1,6 vezes mais contaminado, em média, para tebuconazol, clomazona, carbofurano e bispiribaque de sódio, respectivamente. Apenas o clomazona e o tebuconazol apresentaram concentrações dentro do limite aceitável estabelecidos pelo Codex Alimentarius $\left(0,1 \mathrm{mg} \mathrm{kg}^{-1}\right)$ para o arroz beneficiado nas safras analisadas.
\end{abstract}

Pesticides are used to prevent pests from attacking grains in order to preserve the crops. This paper aims at evaluating the distribution of the pesticides bispyribac-sodium, carbofuran, clomazone and tebuconazole in different fractions of milled rice (white rice, rice bran, husked rice, parboiled rice, parboiled rice bran, and husked parboiled rice) which is planted on experimental fields under controlled conditions. The QuEChERS method was adapted to the extraction of pesticides and validated by using HPLC-DAD for quantification and LC-MS for confirmation. The analytical method of extracting pesticides, as well as the chromatographic conditions for identification and quantification, were suitable, according to certain efficiency indicators: $0.07 \mathrm{mg} \mathrm{kg}^{-1} \mathrm{LOD}$ and $0.2 \mathrm{mg} \mathrm{kg}^{-1} \mathrm{LOQ}$ for the mixture of pesticides and rice and rice bran recoveries of 119 and $116 \%$, 84 and 119\%, 113 and 96\%, 103 and 97\% for carbofuran, bispyribac-sodium, clomazone and tebuconazole, respectively. The method under development was applied to rice fractions: bran had the highest residue concentration of the studied pesticides, when compared to milled rice, showing 8.0, 2.3, 2.2 and 1.6 times more contamination, in average, with tebuconazole, clomazone, carbofuran and bispyribac-sodium, respectively. Only clomazone and tebuconazole were in the acceptable limits established by Codex Alimentarius $\left(0.1 \mathrm{mg} \mathrm{kg}^{-1}\right)$ for milled rice.

Keywords: pesticides, QuEChERS method, rice analysis, liquid chromatography

*e-mail: dorsgi@yahoo.com.br 


\section{Introduction}

Pesticides are used to prevent pests from attacking grains in order to preserve the crops. These compounds have been shown to be toxic to humans and animals because they are carcinogenic, mutagenic, teratogenic and hormone mimickers, besides having the ability to persist in the environment. ${ }^{1-3}$ Depending on their chemical characteristics, the amount of pesticides and other biotic and abiotic conditions, these compounds may migrate into the grain. According to recommendations, pesticides should only be present on the outer layer and should be eliminated during grain milling, mostly in coproducts such as bran and husk. Nevertheless, there are few studies that have been carried out in order to analyze the distribution of contaminants in irrigated rice milling, especially in the inner portions. It is essential to adjust the use of pesticides and minimize contamination because of its consumption.

The world production of husked rice in 2009/10 was 682 million tonnes. ${ }^{4}$ The Brazilian production reached 11.36 million tons in 2009/10, while southern Brazil produced about $72 \%$; Rio Grande do Sul is the main producer with $61 \%$.

The most common multiresidue method used for pesticide analysis involves an initial extraction phase with acetone, acetonitrile or ethyl acetate and other moderately polar solvents; the analytes of interest are transferred to an organic layer, whereas the undesirable co-extractives and some highly polar pesticides remain in the liquid phase. ${ }^{6-13}$ Anastassiades et al. ${ }^{14}$ developed an analytical method that is rapid, easy, cheap, efficient, robust and safe to monitor pesticide residues (QuEChERS). This method has advantages and possibilities provided by modern analytical tools. Besides, it was developed to generate extracts that are directly applicable to gas and liquid chromatography analysis.

The method involves an extraction with acetonitrile, liquidliquid partitioning after the addition of magnesium sulfate and sodium chloride mix; it makes the removal of a significant amount of polar components from the matrix easier. Finally, in the single purification step, the extract is mixed with the solvent. The advantages include rapidity, simplicity, reliability, robustness, low cost and reduced solvent use and it almost does not require the use of laboratory glassware, besides covering a broad range of extracted pesticides such as acidic, alkaline and highly polar ones. ${ }^{13,15}$

High performance liquid chromatography (HPLC) is a technique applied to routine analyses in many different areas, including food. The use of different types of detectors helps in the identification and quantification of compounds. ${ }^{16}$ It is widely used nowadays due to its advantages in relation to gas chromatography (GC), since there is a trend towards the use of more polar pesticides (they are considered more readily degradable ${ }^{17,18}$ and cannot be directly analyzed using $\mathrm{GC}$ at volatilization temperatures). Consequently, there is a need to develop methods using HPLC to determine these compounds and their metabolites. ${ }^{19,20}$ Detection can be accomplished using simple and rapid procedures such as diode array detector (DAD). ${ }^{21,22}$ Mass espectrometry detectors (LC-ESI-MS/MS) coupled to chromatographs lead to a conclusive identification of separated compounds based on the fragmentation of the ions after being submitted to an electromagnetic field. They can be used for result confirmation of other detection systems or for quantification. ${ }^{23}$

Therefore, this study aimed at evaluating the distribution of pesticides (bispyribac-sodium, carbofuran, clomazone and tebuconazole) recommended for irrigated rice in different fractions resulting from rice milling. Thus, a method employing QuEChERS and HPLC-DAD was validated for the extraction and quantification, besides LC-MS, for confirmation, in order to determine multiple classes of pesticides in rice grain and rice bran. They are matrices with high carbohydrate, lipid, protein and fiber contents.

\section{Experimental}

\section{Reagents and chemicals}

The following chemical reagents were used in this study: acetonitrile and methanol HPLC-grade (J. T. Baxter), hexane p.a., sodium chloride and phosphoric acid p.a. $85 \%$ (Merck). Water was purified with the Direct-Q UV3 ${ }^{\circledR}$ system, resistivity 18.2 $\mathrm{M} \Omega \mathrm{cm}$ (Millipore, Bedford, MA, USA). The pesticide standards used in this study, as well as their suppliers, purity degree, class, chemical group, toxicological class and chemical structures are shown in Table 1.

\section{Preparation of the analytical solutions}

The stock pesticide solutions were individually prepared by dissolving the respective analytical standards in acetonitrile in order to obtain concentrations of $1000 \mathrm{mg} \mathrm{L}^{-1}$. Work solutions were then prepared from these stock solutions at a concentration of $100 \mathrm{mg} \mathrm{L}^{-1}$. These solutions were used for the fortification and the preparation of the analytical curve solutions. All solutions were stored in amber flasks at $-18{ }^{\circ} \mathrm{C}$ and stirred in an ultrasound bath before use.

\section{Instrumentation}

HPLC-DAD was performed by using an HPLC apparatus consisting of a Waters 600 pump model, associated with a 
Table 1. Description of the solid analytical standards

\begin{tabular}{|c|c|c|c|c|c|c|}
\hline Compounds & Suppliers & $\begin{array}{c}\text { Purity } \\
\text { Degree / }(\%)\end{array}$ & Class & Chemical Group & $\begin{array}{c}\text { Toxicological } \\
\text { class }\end{array}$ & Chemical structure \\
\hline Tebuconazole & Sigma Aldrich & 99.6 & Fungicide & Triazole & III & \\
\hline Bispyribac-sodium & Dr. Ehrenstorfer & 99.0 & Herbicide & $\begin{array}{c}\text { Pyrimidinyl } \\
\text { oxybenzoic acid }\end{array}$ & III & \\
\hline Carbofuran & Sigma Aldrich & 98.8 & $\begin{array}{l}\text { Insecticide / } \\
\text { nematicide }\end{array}$ & $\begin{array}{c}\text { Benzofuranyl } \\
\text { methylcarbamate }\end{array}$ & I & \\
\hline Clomazone & Sigma Aldrich & 97.4 & Herbicide & Isoxazolidinone & III & \\
\hline
\end{tabular}

Toxicity class: I most toxic; II moderately toxic; III slightly toxic.

Waters 2996 Photodiode Array Detector, Rheodyne $20 \mu \mathrm{L}$ loop injector, and connected to an Empower PDA software for data acquisition. The UV spectra were recorded in the 210-400 nm range.

Two analytical columns were tested: WATERS Spherisorb ODS2 C18 $(150 \mathrm{~mm} \times 4.6 \mathrm{~mm}, 5 \mu \mathrm{m})$ and PHENOMENEX Synergi Fusion-RP 80A $(250 \mathrm{~mm} \times$ $4.6 \mathrm{~mm}, 4 \mu \mathrm{m})$.

Liquid chromatography with mass spectrometric detection (LC-MS) was performed in a Waters Alliance 2695 Separations Module fitted with an autosampler, a membrane degasser and a quaternary pump. Mass spectrometry was performed on a Micromass Quattro Micro API with an ESI interface. Analytical instrument control, data acquisition and treatment were performed by software Masslynx version 4.1, 2005 (Waters, Milford, MA, USA). The column was Waters X Terra MS C18, $(50 \mathrm{~mm} \times 3 \mathrm{~mm}, 3.5 \mu \mathrm{m})$.

\section{Adequacy of the HPLC-DAD separation and detection process}

To choose the mobile phase composition, different ratios of solvents (methanol, acetonitrile, Milli-Q water and Milli-Q water at $\mathrm{pH} 3.0$ acidified with phosphoric acid $1: 1 \mathrm{v} / \mathrm{v}$, adjusted with a $\mathrm{pH}$ meter), deaerated in ultrasound bath for $30 \mathrm{~min}$ at room temperature were tested. The choice of the flow rate was based on experimental tests ranging from 0.8 to $1.0 \mathrm{~mL} \mathrm{~min}^{-1}$. Before determinations were made, the system was conditioned by the elution of the best chromatographic conditions for $1 \mathrm{~h}$.

Maximum absorption spectra at the ultraviolet region were obtained by injecting each pesticide separately. Chromatographic peaks of the active principles were obtained; firstly, they were injected into the chromatograph under the same conditions and retention times were confirmed by the separate addition of the standards to the mix of the four compounds. The increase of the signal of the pesticide which was added, compared with the spectra obtained without the addition, confirmed the retention time. Afterwards, the mix of the four pesticides was injected to choose a wavelength that enabled their simultaneous visualization.

\section{HPLC-DAD validation}

The linearity of the determination was tested by preparing solutions at concentrations ranging from 0.1 to $10 \mathrm{mg} \mathrm{L}^{-1}$, injected in triplicate. Standard peak area means were calculated in their respective maximum absorption wavelengths. The slope of the concentration: signal ratio and the coefficient of determination $\left(\mathrm{r}^{2}\right)$ were then estimated.

The limit of detection (LOD) of the instrument was determined considering the concentration whose chromatographic signal was threefold the signal of the baseline noise at the retention time of the peaks of interest. The limit of quantification (LOQ) of the instrument was considered as being the LOD value threefold.

\section{LC-MS for confirmation of pesticides}

The LC-MS chromatograph was conditioned by passing the mobile phase acetonitrile:water (70:30, v/v) both acidified with $0.1 \%(\mathrm{v} / \mathrm{v})$ formic acid. The injection volume was $10 \mu \mathrm{L}$ and the flow rate was $0.5 \mathrm{~mL} \mathrm{~min}{ }^{-1}$. For the mass/charge ratio sign optimization, a solution of each pesticide at a concentration of $1 \mu \mathrm{g} \mathrm{mL}^{-1}$ was injected. From the infusion of pesticide individual solutions, the best conditions for the fragmentation of monitored ions were determined. 
For linearity determination, six standard concentrations (0.001, 0.01, 0.05, 0.1, 0.5 and $\left.1.0 \mathrm{mg} \mathrm{L}^{-1}\right)$ were injected three times. The equation and coefficients of variation were calculated from the logged area values.

\section{Modification of the QuEChERS method}

The samples (rice grain and rice bran) in triplicate were fortified at the concentration of $1 \mathrm{mg} \mathrm{kg}^{-1}$ for the tests and compared to a sample that was not fortified with pesticides. The concentration of the pesticides recovered during quantification was the criterion used for measuring the adequacy of the extraction. Table 2 shows the procedure changes made in the QuEChERS method, modified by Prestes et al. ${ }^{24}$ for the compounds under analysis.

Table 2. Conditions tested for the adaptation of the QuEChERS method

\begin{tabular}{lc}
\hline Variables & Modification tested \\
\hline Sample quantity & 1,10 and $25 \mathrm{~g}$ \\
Sample:water ratio $(\mathrm{p} / \mathrm{p})$ & $1: 1$ and $1: 2$ \\
Sample soaking time & 30 and $60 \mathrm{~min}$ \\
Slurry mass & 1,10 and $20 \mathrm{~g}$ \\
Slurry mass/acetonitrile (suspension) ratio $(\mathrm{p} / \mathrm{p})$ & $1: 1$ and $1: 2$ \\
Anhydrous magnesium sulfate mass & 3 and $5 \mathrm{~g}$ \\
Sodium acetate mass & 0 and $1.7 \mathrm{~g}$ \\
C18 mass & 0 and $600 \mathrm{mg}$ \\
Suspension with alcoholic KOH $0.5 \%$ & 0 and $10 \mathrm{~mL}$ \\
Suspension with SDS $>2.5 \%$ & 0 and $10 \mathrm{~mL}$ \\
Reduction of the extracted volume & yes and no \\
Extract freezing & yes and no \\
Millipore filtration before injection & yes and no \\
\hline
\end{tabular}

\section{Samples}

Rice grain and rice bran samples used for validation of the multiresidue method were purchased in the retail market. Rice was ground by a multi-purpose mill (Tecnal, Te-631). Fractions that passed through a $32 \mathrm{mesh}(0.5 \mathrm{~mm})$ were separated through sieving for analysis.

The study of pesticides distribution was carried out in rice samples cultivated on experimental fields at the Instituto Riograndense de Arroz (IRGA) located in Cachoeirinha, Rio Grande do Sul, Brazil, in two sequential harvests. BRIRGA 417 rice was sowed at a density of $100 \mathrm{~kg} \mathrm{ha}^{-1}$. Four hundred $\mathrm{kg} \mathrm{ha}^{-1}$ of a fertilizer (N:P:K = 05:20:30) was used. Eighty $\mathrm{kg} \mathrm{ha}^{-1}$ of nitrogen was applied before irrigation, when the plants had three leaves. When they had 8 leaves, $40 \mathrm{~kg} \mathrm{ha}^{-1}$ of nitrogen was applied before the beginning of the differentiation of the panicle primordium. The pesticides clomazone $\left(600 \mathrm{~mL} \mathrm{ha}^{-1}\right)$ and bispyribac-sodium $\left(150 \mathrm{~mL} \mathrm{ha}^{-1}\right)$ were applied; the former was used before the first top-dressing and the latter, after the second top-dressing. Carbofuran $\left(4 \mathrm{~kg} \mathrm{ha}^{-1}\right)$ was also applied after the third topdressing $\left(50 \mathrm{~kg} \mathrm{ha}^{-1}\right.$ urea and $\left.50 \mathrm{~kg} \mathrm{ha}^{-1} \mathrm{KCl}\right)$.

In order to study the effect of the fungicide, an experiment with random groups was carried out. They were threefold and underwent two treatments: T1 - no fungicide application; T2 - tebuconazole was applied at the beginning of the panicle (R3-R4) at $0.75 \mathrm{~L} \mathrm{ha}^{-1}$ as an emulsionable concentrate (EC).

After harvest, samples were dried up to $13 \%$ humidity, milled as natural polished rice (white rice) and parboiled in the test mill Zacarria PAZ1DTA. Parboiling was carried out in the laboratory in a 1:1.5 ratio grain mass:water at $65 \pm 2{ }^{\circ} \mathrm{C}$ for $5 \mathrm{~h}$, autoclaved at $116 \pm 1{ }^{\circ} \mathrm{C}$ and pressure of $0.6 \pm 0.05 \mathrm{kPa}$ for $10 \mathrm{~min}$. It was initially dried at $50 \pm 2{ }^{\circ} \mathrm{C}$ up to $18 \%$ humidity and then, at $40 \pm 1^{\circ} \mathrm{C}$ up to $13 \%$ humidity. ${ }^{25}$

During polishing and parboiling, the following fractions were separated: husked rice, rice bran and amilaceous endosperm. Afterwards, fractions were ground and separated after sieving (32 and 65 mesh), codified and stored at $-18{ }^{\circ} \mathrm{C}$ until they were analyzed.

\section{Modified QuEChERS method}

After establishing the separation conditions and modifications tested for the extraction method, the modified QuEChERS method consisted of weighing $10 \mathrm{~g}$ of sample, stirring it in $20 \mathrm{~mL}$ Milli-Q water to form slurry. After this procedure, the slurry should be left to rest for $1 \mathrm{~h}$ and stirred again.

For the extraction, $10 \mathrm{~g}$ slurry was weighed in a polypropylene tube with a threaded cover $(50 \mathrm{~mL}$ capacity) to which $20 \mathrm{~mL}$ acetonitrile, containing $1 \%$ acetic acid, was added. The slurry was then vertically stirred by hand for $45 \mathrm{~s}$. Then, $5 \mathrm{~g}$ anhydrous magnesium sulfate was added and stirred. The tubes were then centrifuged at $5000 \mathrm{rpm}$ for ten minutes and the supernatant (extract) was evaporated to $10 \mathrm{~mL}$, frozen and injected into HPLC-DAD and LC-MS.

\section{Accuracy and precision}

The accuracy of the method was evaluated in terms of recovery. The recovery of the compounds under study was evaluated after fortification of the samples (rice grain and rice bran) with the analytical solution $10 \mathrm{mg} \mathrm{kg}^{-1}$ at three concentration levels (1, 5 and 10 times higher than the LOQ, according ANVISA ${ }^{26}$ ). The precision of the method was evaluated in terms of repeatability $\left(\mathrm{RSD}_{\mathrm{r}}\right)$ and intermediate precision $\left(\mathrm{RSD}_{\mathrm{ip}}\right)$. In order to assess the $\mathrm{RSD}_{\mathrm{r}}$ and $\mathrm{RSD}_{\mathrm{ip}}$, 
fortification, extraction and quantification in triplicate were performed for every fortification level, resulting in $\mathrm{n}=9$ ( 3 extractions $\times 3$ injections each). RSD ${ }_{\mathrm{ip}}$ was performed on two different days.

\section{Application of the modified method}

The modified method was used for extraction and pesticide residue analysis in the samples cultivated on the experimental fields and milled, resulting in husked rice, husked parboiled rice, white rice, parboiled rice, white rice bran and parboiled rice bran as described in the section Samples. All the analyses were made in triplicate.

\section{Results and Discussion}

\section{Chromatographic conditions}

According to Pareja et al. ${ }^{27}$ the GC determination is impossible in the case of some pesticides because of their polarity, low thermal stability or lack of volatility. Therefore, LC is an alternative for the analysis of these compounds when the most used detectors are UV, diode array detector (DAD) and MS.

The best chromatographic conditions attained for the separation and detection of the pesticides in the HPLCDAD system were: analytical column Synergi Fusion-RP $80 \mathrm{~A}(250 \times 4.6 \mathrm{~mm}, 4 \mu \mathrm{m})$; mobile phase acetonitrile/water (70:30 v/v) adjusted for $\mathrm{pH} 3.0$ with $\mathrm{H}_{3} \mathrm{PO}_{4}(1: 1 \mathrm{v} / \mathrm{v})$ and flow rate of $0.8 \mathrm{~mL} \mathrm{~min}^{-1}$; detector diode array, monitoring at $220 \mathrm{~nm}$; injection loop $20 \mu \mathrm{L}$ and analysis time of $12 \mathrm{~min}$.

The maximum absorption spectra for each pesticide were determined by injecting a solution of $1.0 \mathrm{mg} \mathrm{L}^{-1}$ and the results were used to confirm the identity of the analytes by comparing the spectra obtained from the standards with the samples and to quantify every component from the analytical curve. The maximum wavelength of $220 \mathrm{~nm}$ was chosen because it enabled the monitoring of all pesticides. Under these conditions, Figure 1 shows the profile of a typical separation chromatogram in the LOQ concentration and the spectra of the compounds.
Table 3 shows the equations, coefficient of determination $\left(\mathrm{r}^{2}\right)$ and linear range. The method shows good linearity, since $r^{2}>0.999$ is considered evidence of an optimal fit of the data for the regression line. ${ }^{28,29}$ The method sensitivity was higher for clomazone and tebuconazole according to the angular coefficients of these equations, which showed higher variation in the concentration to signal ratio. ${ }^{30}$

\section{Sample preparation by the QuEChERS method}

The QuEChERS method has been developed as an alternative for sample preparation for the analysis of multiple pesticide residues in fruits and vegetables because of its simplicity, low cost, relatively high efficiency and minimal number of steps. It is used for food analysis because it combines several steps and extends the range of pesticides recovered over older, more tedious extraction techniques. In recent years, several modifications have been introduced to the original method, aiming to improve the recoveries of some problematic pesticides and to analyze complicated matrices. The traditional methods of determining pesticides in food are usually multi-stage procedures, requiring large samples and one or more extract cleanup steps. Therefore, they are time-consuming, labor-intensive, complicated, and expensive. They also generate considerable amounts of waste. ${ }^{13,27}$ To optimize the QuEChERS method, rice bran was used because it is the rice co-product with the most complex matrix. It has, in average, $13-15 \%$ protein, $15-17 \%$ lipids and $8.5-10 \%$ fiber. ${ }^{31,32}$

In order to better define the extraction method for the compounds under study, some different variables were tested. They were based on the QuEChERS method modified by Prestes et al. ${ }^{24}$ who uses the same rice mass, lower acetonitrile volume, $15 \mathrm{~s}$ stirring and lower masses of magnesium sulfate and sodium acetate for extraction. Additionally, $\mathrm{C} 18$ was used for cleanup and determination of pesticides in GC-MS with recovery rates ranging from $70 \%$ to $120 \%$.

After tests were performed, the basic changes in the method were related to slurry preparation. According to the original method, ${ }^{14}$ samples with low moisture content

Table 3. Linear range, LOD and LOQ methods, analytical curve and coefficient of determination in HPLC-DAD and LC-MS

\begin{tabular}{|c|c|c|c|c|c|c|c|}
\hline \multirow[b]{2}{*}{ Pesticides } & \multicolumn{5}{|c|}{ HPLC-DAD } & \multicolumn{2}{|l|}{ LC-MS } \\
\hline & Linear equation & $\mathrm{r}^{2}$ & $\begin{array}{l}\text { Linear range / } \\
\left(\mathrm{mg} \mathrm{kg}^{-1}\right)\end{array}$ & $\begin{array}{c}\text { LOD / } \\
\left(\mathrm{mg} \mathrm{kg}^{-1}\right)\end{array}$ & $\begin{array}{c}\mathrm{LOQ} / \\
\left(\mathrm{mg} \mathrm{kg}^{-1}\right)\end{array}$ & Linear equation & $r^{2}$ \\
\hline Carbofuran & $y=55200 x-201$ & 0.998 & $0.1-10$ & 0.07 & 0.2 & $y=306.818 x+0.692$ & 0.992 \\
\hline Bispyribac-sodium & $y=46800 x-741$ & 0.998 & $0.1-10$ & 0.07 & 0.2 & $y=109.754 x+(-0.087)$ & 0.992 \\
\hline Clomazone & $y=78300 x-1150$ & 0.999 & $0.1-10$ & 0.07 & 0.2 & $y=3010.900 x+12.044$ & 0.992 \\
\hline Tebuconazole & $y=84800 x-1470$ & 0.999 & $0.1-10$ & 0.07 & 0.2 & $y=4517.360 x+13.949$ & 0.990 \\
\hline
\end{tabular}


(A)

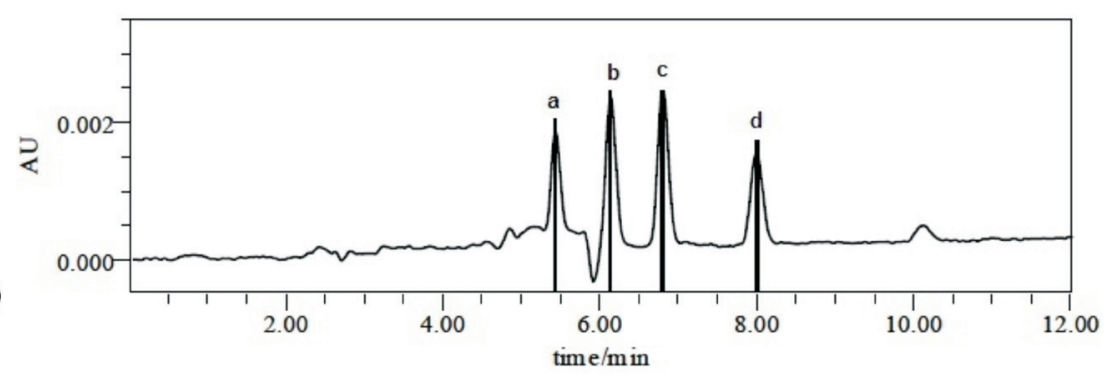

(B)

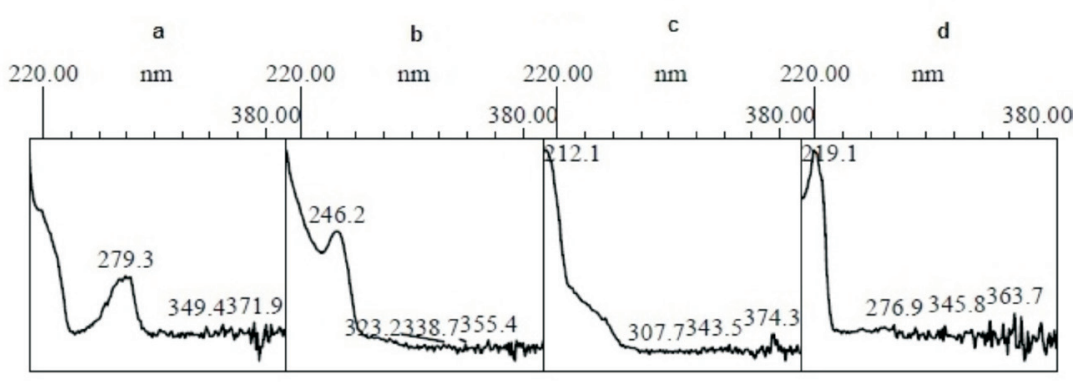

(a) carbofuran; (b) bispyribac-sodium; (c) clomazone; (d) tebuconazole

Figure 1. Chromatogram at LOQ concentration (A) and UV spectra (B). (HPLC conditions: monitoring at 220 nm; Synergi Fusion-RP 80A column; mobile phase acetonitrile/water $(70: 30 \mathrm{v} / \mathrm{v})$ adjusted for $\mathrm{pH} 3.0$ with $\mathrm{H}_{3} \mathrm{PO}_{4}(1: 1 \mathrm{v} / \mathrm{v})$ and flow rate of the $\left.0.8 \mathrm{~mL} \mathrm{~min}^{-1}\right)$.

$(<80 \%)$ require the addition of water before extraction is started in order to improve the ability to extract compounds with the formation of pores that enable a better access to the extraction solvent. The best ratio for the preparation of the rice bran slurry was $1: 2$ (bran:water, $\mathrm{m} / \mathrm{m}$ ), i.e., $10 \mathrm{~g}$ rice bran for $20 \mathrm{~g}$ Milli-Q water. The same ratio was used to prepare the rice slurry, with a resting time of $1 \mathrm{~h}$ before weighing for extraction, because sample preparation involves extraction and pre-concentration techniques. These steps should be followed in order to promote sample fractionation and enrichment with all the analytes of interest, freeing them from interferences which result from the matrix components. ${ }^{33}$ Pareja et al. ${ }^{27}$ reported modifications made in the original method such as the salts, their quantity and the amount of primary secondary amine or addition of acetic acid or formic acid to the extraction solvent, and the use of low temperature during the clean-up step. In this study, the increase in the amount of extraction solvent from 10 to $20 \mathrm{~mL}$ acidified acetonitrile and in the stirring time (from 15 to $45 \mathrm{~s}$ ) improved the final recovery because solvent saturation was prevented, therefore avoiding the resulting loss of the compounds under analysis. The increase in the amount of magnesium sulfate from 3 to $5 \mathrm{~g}$ also led to increased recovery, since the addition of this extract in the presence of water can promote the formation of a non-solubilized salt agglomerate which is dissolved by stirring the tube immediately.

The sodium acetate was not used and cleanup was not performed by Prestes et al. $;^{24}$ instead, the extract concentration was reduced to half its volume and the extract was frozen before injection in HPLC-DAD. Freezing the extract water destabilizes the some interfering compounds, namely proteins that are found in large amounts in rice bran, which then precipitate in the slightly acidified medium, leaving a clear extract which does not require filtering. At freezer or refrigerator temperature, fats are easily removed from the extract, so, it is a simple clean-up step that provides cleaner extracts for the analysis of unpolished rice, but a possible disadvantage is that some liposoluble compounds can be lost. The freezing-out clean up is also reported for cereals and dry animal feed, as a practical way to reduce the amounts of co-extractants, thereby improving identification and quantitation of certain pesticides..$^{27}$

Table 4 shows the recovery values of the procedure and the reproducibility $\left(\mathrm{RSD}_{\mathrm{r}}\right)$ and intermediate precision $\left(\mathrm{RSD}_{\mathrm{ip}}\right)$ values.

In food, both precision and accuracy of the determinations are dependent on the matrix complexity, the analyte concentration and the analysis technique. Precision can range from $2 \%$ to $20 \%,{ }^{27-29,34}$ as for accuracy, recoveries can range from $70 \%$ to $120 \% .{ }^{27,28,35}$ Considering the results shown in Table 4, both $\mathrm{RSD}_{\mathrm{r}}$ and $\mathrm{RSD}_{\text {ip }}$ ranged from $1 \%$ to $20 \%$ and the recovery rate, from $81 \%$ to $121 \%$. Therefore, the method is in accordance with the recommended parameters for procedure efficiency.

All the sample-preparation techniques have advantages and disadvantages, depending especially on the type of pesticide and rice commodity combination, so it seems that, for rice commodities there is not a universal multiresidue methodology whose performance has been proved 
Table 4. Recovery, $\mathrm{RSD}_{\mathrm{r}}$ and $\mathrm{RSD}_{\mathrm{ip}}$ of the method used for pesticides in rice grain and rice bran

\begin{tabular}{|c|c|c|c|c|c|c|}
\hline Pesticides & $\begin{array}{c}\text { Fortification } \\
\text { level }\end{array}$ & $\begin{array}{l}\text { Recovery in } \\
\text { rice grain / }(\%)^{* *}\end{array}$ & $\begin{array}{c}\text { Recovery in } \\
\text { rice bran / }(\%)^{* *}\end{array}$ & $\begin{array}{c}\mathrm{RSD}_{\mathrm{r}} \\
\text { rice bran / }(\%)^{*}\end{array}$ & $\begin{array}{c}\mathrm{RSD}_{\mathrm{ip}} \\
\text { rice bran / }(\%)^{* *}\end{array}$ & $\begin{array}{c}\operatorname{RSD}_{\mathrm{r}} \\
\text { rice grain / (\%)* }\end{array}$ \\
\hline \multirow[t]{3}{*}{ Carbofuran } & $1 \mathrm{LOQ}$ & 118 & 114 & 20 & 8 & 2 \\
\hline & $5 \mathrm{LOQ}$ & 121 & 116 & 15 & 1 & 2 \\
\hline & 10 LOQ & 117 & 119 & 12 & 18 & 14 \\
\hline \multirow[t]{3}{*}{ Bispyribac-sodium } & $1 \mathrm{LOQ}$ & 81 & 117 & 18 & 6 & 2 \\
\hline & $5 \mathrm{LOQ}$ & 85 & 119 & 14 & 4 & 9 \\
\hline & $10 \mathrm{LOQ}$ & 86 & 120 & 13 & 4 & 2 \\
\hline \multirow[t]{3}{*}{ Clomazone } & $1 \mathrm{LOQ}$ & 114 & 94 & 14 & 2 & 2 \\
\hline & $5 \mathrm{LOQ}$ & 110 & 95 & 12 & 15 & 9 \\
\hline & $10 \mathrm{LOQ}$ & 115 & 98 & 17 & 3 & 1 \\
\hline \multirow[t]{3}{*}{ Tebuconazole } & $1 \mathrm{LOQ}$ & 105 & 99 & 20 & 4 & 2 \\
\hline & $5 \mathrm{LOQ}$ & 101 & 95 & 12 & 16 & 2 \\
\hline & 10 LOQ & 103 & 98 & 15 & 7 & 3 \\
\hline
\end{tabular}

$*_{\mathrm{n}}=3$ ( 3 injections of each extract); $*^{*} \mathrm{n}=9\left(3\right.$ extractions $\times 3$ injections of each extract); ${ }^{*} 1 \mathrm{LOQ}=0.2 \mathrm{mg} \mathrm{kg}^{-1} ; 5 \mathrm{LOQ}=1.0 \mathrm{mg} \mathrm{kg}{ }^{-1} ; 10 \mathrm{LOQ}=2.0 \mathrm{mg} \mathrm{kg}{ }^{-1}$.

sufficiently. Multiclass, multiresidue methods (MRMs) are undoubtedly one way of addressing the problem of pesticide determination, given the great diversity of this group of compounds. However, the complex sample matrix may contain abundant quantities of chlorophyll, lipids, sterols and other components that can interfere with sample analysis, but there is not a universal multiresidue methodology whose performance has been considered the best. QuEChERS is a very versatile method that enables working at different $\mathrm{pHs}$, and several modifications can be performed at the dispersive clean-up step to extend the range of pesticides that can be analyzed. Moreover, it is simple, cheap and environmentally friendly, as the solvent consumption is lower than that of other methodologies. Besides, it needs practically no glassware..$^{13,27}$

After the validation of the QuEChERS method in the HPLC-DAD system, pesticide standards were injected into the LC-MS in order to find the best chromatographic conditions for the compound confirmation. LC-MS reduces the need for excessive clean up, resulting in reduced costs and time. It is generally combined with single-quadrupole or triple-quadrupole systems, quadrupole linear ion trap, or time-of-flight spectrometers or hybrid quadruple instruments. LC-MS applications reported for the analyses of pesticides in rice are performed with two different ionization techniques, electrospray ionization (ESI) and APCI. However, generally ESI is more often used. ${ }^{27}$

The compounds under study responded better in positive mode using electrospray ionization, with source temperature set at $100{ }^{\circ} \mathrm{C}$, desolvation gas temperature at $350{ }^{\circ} \mathrm{C}$. Flow rates of nitrogen gas for sample desolvation and sample cone were respectively 350 and $50 \mathrm{~L} \mathrm{~h}^{-1}$. Since LC-MS was used as a confirmatory method in this case, two stable fragments were chosen, and, with these transitions and their specific retention times, the presence of pesticides in samples quantified by HPLC-DAD was confirmed. Table 5 shows the fragmentation conditions for each pesticide and Table 3 presents the equations and coefficients of determination $\left(\mathrm{r}^{2}\right)$.

Separation, quantification and confirmation of the pesticides in the samples

The method that was chosen and validated was applied to the samples cultivated on the IRGA experimental fields and the results are shown in Table 6.

The statistical evaluation of results in Table 6 points out that tebuconazole was the only pesticide that showed significant difference from one harvest to another, because it was the only pesticide that varied in the treatments on the experimental fields. By comparing the samples of each pesticide under evaluation, it was verified that bispyribacsodium and clomazone did not present significant differences, that is, grain milling and/or processing did not significantly affect the amount of residues. However, the same did not occur with carbofuran and tebuconazole, which presented large differences depending on the milling and/or process. The parboiling process contributed to the carbofuran and bispyribac-sodium migration to the starchy endosperm, but the same was not verified for clomazone and tebuconazole.

Some authors reported the effect of parboiling rice when using different pesticides and the results showed a significant reduction of residues in the parboiled paddy bran, depending upon the pesticide. They concluded that 
Table 5. Chromatographic conditions for pesticide confirmation in LC-MS (dwell time: $0.3 \mathrm{~s}$ )

\begin{tabular}{|c|c|c|c|c|}
\hline Pesticides & Cone voltage / V & Precursor ion $/(\mathrm{m} / \mathrm{z})$ & Collision energy / eV & Ion product $/(\mathrm{m} / \mathrm{z})$ \\
\hline \multirow[t]{2}{*}{ Carbofuran } & 25 & 222 & 20 & 123 \\
\hline & 25 & 222 & 20 & 165 \\
\hline \multirow[t]{2}{*}{ Bispyribac-sodium } & 35 & 453 & 22 & 275 \\
\hline & 35 & 453 & 25 & 297 \\
\hline \multirow[t]{2}{*}{ Clomazone } & 30 & 240 & 15 & 100 \\
\hline & 25 & 240 & 20 & 125 \\
\hline \multirow[t]{2}{*}{ Tebuconazole } & 40 & 308 & 20 & 70 \\
\hline & 33 & 308 & 50 & 88 \\
\hline
\end{tabular}

Table 6. Pesticide contents determined in the samples

\begin{tabular}{|c|c|c|c|c|}
\hline Samples & $\begin{array}{c}\text { Carbofuran / } \\
\left(\mathrm{mg} \mathrm{kg}^{-1}\right)\end{array}$ & $\begin{array}{l}\text { Bispyribac-sodium / } \\
\left(\mathrm{mg} \mathrm{kg}^{-1}\right)\end{array}$ & $\begin{array}{l}\text { Clomazone / } \\
\left(\mathrm{mg} \mathrm{kg}^{-1}\right)\end{array}$ & $\begin{array}{c}\text { Tebuconazole / } \\
\left(\mathrm{mg} \mathrm{kg}^{-1}\right)\end{array}$ \\
\hline \multicolumn{5}{|l|}{ Harvest 1} \\
\hline White rice grain (NT) & $0.7^{\mathrm{Aa}}$ & $0.8^{\mathrm{Aa}}$ & $<\mathrm{LOQ}^{\mathrm{Aa}}$ & $\mathrm{nd}^{\mathrm{Aa}}$ \\
\hline White rice grain $(\mathrm{T})$ & $1.3^{\mathrm{Aa}}$ & $1.7^{\mathrm{Aa}}$ & $0.2^{\mathrm{Aa}}$ & $0.2^{\mathrm{Aa}}$ \\
\hline Rice bran (NT) & $1.1^{\mathrm{Aab}}$ & $1.6^{\mathrm{Aa}}$ & $1.0^{\mathrm{Aa}}$ & $<\mathrm{LOQ}^{\mathrm{Aa}}$ \\
\hline Rice bran $(\mathrm{T})$ & $3.7^{\mathrm{Aabc}}$ & $2.0^{\mathrm{Aa}}$ & $1.4^{\mathrm{Aa}}$ & $1.5^{\mathrm{Abc}}$ \\
\hline \multicolumn{5}{|l|}{ Harvest 2} \\
\hline White rice grain (NT) & $\mathrm{nd}^{\mathrm{Aa}}$ & $\mathrm{nd}^{\mathrm{Aa}}$ & $\mathrm{nd}^{\mathrm{Aa}}$ & $\mathrm{nd}^{\mathrm{Ba}}$ \\
\hline White rice grain $(\mathrm{T})$ & $\mathrm{nd}^{\mathrm{Aa}}$ & $\mathrm{nd}^{\mathrm{Aa}}$ & $<\mathrm{LOQ}^{\mathrm{Aa}}$ & $\mathrm{nd}^{\mathrm{Ba}}$ \\
\hline Rice bran (NT) & $1.4^{\mathrm{Aab}}$ & $1.1^{\mathrm{Aa}}$ & $1.6^{\mathrm{Aa}}$ & $0.3^{\mathrm{Ba}}$ \\
\hline Rice bran $(\mathrm{T})$ & $3.4^{\mathrm{Aabc}}$ & $3.3^{\mathrm{Aa}}$ & $2.0^{\mathrm{Aa}}$ & $1.4^{\mathrm{Bbc}}$ \\
\hline Husked rice (NT) & $4.9^{\mathrm{Abc}}$ & $1.3^{\mathrm{Aa}}$ & $1.5^{\mathrm{Aa}}$ & $1.9^{\mathrm{Bc}}$ \\
\hline Husked rice $(\mathrm{T})$ & $6.5^{\mathrm{Ac}}$ & $5.9^{\mathrm{Aa}}$ & $2.4^{\mathrm{Aa}}$ & $5.2^{\mathrm{Bd}}$ \\
\hline Parboiled rice (NT) & $\mathrm{nd}^{\mathrm{Aa}}$ & $0.4^{\mathrm{Aa}}$ & $\mathrm{nd}^{\mathrm{Aa}}$ & $\mathrm{nd}^{\mathrm{Ba}}$ \\
\hline Parboiled rice $(\mathrm{T})$ & $2.2^{\mathrm{Aabc}}$ & $1.8^{\mathrm{Aa}}$ & $\mathrm{nd}^{\mathrm{Aa}}$ & $\mathrm{nd}^{\mathrm{Ba}}$ \\
\hline Parboiled rice bran (NT) & $0.4^{\text {Aab }}$ & $0.2^{\mathrm{Aa}}$ & $0.2^{\mathrm{Aa}}$ & $0.6^{\mathrm{Bb}}$ \\
\hline Parboiled rice bran $(\mathrm{T})$ & $0.6^{\mathrm{Aab}}$ & $0.3^{\mathrm{Aa}}$ & $0.7^{\mathrm{Aa}}$ & $1.5^{\mathrm{Bbc}}$ \\
\hline Husked parboiled rice (NT) & $1.6^{\mathrm{Aab}}$ & $<\mathrm{LOQ}^{\mathrm{Aa}}$ & $<\mathrm{LOQ}^{\mathrm{Aa}}$ & $0.6^{\mathrm{Bab}}$ \\
\hline Husked parboiled rice $(\mathrm{T})$ & $2.4^{\mathrm{Aabc}}$ & $0.7^{\mathrm{Aa}}$ & $0.6^{\mathrm{Aa}}$ & $4.5^{\mathrm{Bd}}$ \\
\hline
\end{tabular}

$\mathrm{nd}=$ not detected; $\mathrm{T}=$ treated with fungicide and $\mathrm{NT}=$ not treated with fungicide. Different capital letters for the same pesticide indicate a significant difference between harvests at $95 \%$ confidence. Different lowercase letters for the same pesticide indicate a significant difference among samples (white rice grain, rice bran, husked rice, parboiled rice, parboiled rice bran, and husked parboiled rice) at $95 \%$ confidence.

this reduction was due to inactivation or degradation of the pesticides during parboiling at high temperature $\left(100^{\circ} \mathrm{C}\right)$. Samples of rough rice, hulls, brown rice, milled rice and cooked rice were also studied; the conclusion was that parboiling reduced residues on rough rice and hulls but tended to increase residues in the other fractions. ${ }^{27}$

The bran fraction, obtained from white rice milling or parboiling showed the highest concentration of pesticide residues, when compared to rice grain (white or parboiled). It was 8.0, 2.3, 2.2 and 1.6 times more contaminated, in average, with tebuconazole, clomazone, carbofuran and bispyribac-sodium, respectively.
By comparing pesticides-treated $(\mathrm{T})$ and non-treated (NT) samples, it was verified that those NT samples showed tebuconazole residues. This fact can be related to soil or irrigation water contamination used for cultivation.

Recommendations for maximum residue limits (MRL) vary in the literature. Comparing the levels of pesticides found in the samples with the highest MRLs values established by Codex Alimentarius ${ }^{36}$ and by ANVISA ${ }^{37}$ for rice grain $\left(0.01 \mathrm{mg} \mathrm{kg}^{-1}\right.$ for bispyribac-sodium; $0.2 \mathrm{mg} \mathrm{kg}^{-1}$ for carbofuran; $0.1 \mathrm{mg} \mathrm{kg}^{-1}$ for clomazone and tebuconazole), it can be concluded that, among all samples under analysis, only tebuconazole and clomazone showed 
concentrations lower than the acceptable limits for white and parboiled rice. It may be pointed out that for whole rice, the risk of levels above the recommended limits may be higher.

In most of the foods, pesticide residues suffer a large reduction during processing, but, in the case of cereals, the concentration of pesticides is reduced more slowly. Investigation of the fate of pesticide residues during processing or cooking is useful not only to evaluate the health risk of the estimated dietary expose but also to establish MRLs and recognize levels of pesticide residues in food. Particularly for rice, changes in the concentration of pesticides occur mainly during milling, cooking, parboiling and washing, but there are few studies of the fate of pesticides during rice processing. ${ }^{27}$

Therefore, results showed that rice husk removal was not enough to eliminate pesticides used in rice cultivation, thus, highlighting the importance of determining these compounds for the knowledge of chronic contamination risk of consumers when rice is part of the diet.

\section{Conclusions}

The modified QuEChERS analytical method was suitable for extracting the pesticides from rice bran and rice grain. Besides, the chromatographic conditions were proper to identify and quantify these components by HPLC-DAD: LOD was $0.07 \mathrm{mg} \mathrm{kg}^{-1}$ and LOQ was $0.2 \mathrm{mg} \mathrm{kg}^{-1}$ for all pesticides. Recoveries for rice and rice bran were 119 and $116 \%, 84$ and $119 \%, 113$ and 96\%, 103 and $97 \%$ for carbofuran, bispyribac-sodium, clomazone and tebuconazole, respectively.

The bran fraction showed the highest concentration of pesticide residues, when compared to rice grain; it is 8.0, 2.3, 2.2 and 1.6 times more contaminated, in average, with tebuconazole, clomazone, carbofuran and bispyribacsodium, respectively. Only clomazone and tebuconazole were within the acceptable limits established by Codex Alimentarius ${ }^{36}$ for milled rice.

\section{References}

1. SOSBAI - Sociedade Sul-Brasileira de Arroz Irrigado; Arroz Irrigado: Recomendações Técnicas da Pesquisa para o Sul do Brasil - V Congresso Brasileiro de Arroz, Irrigado, XXVII Reunião da Cultura do Arroz Irrigado, Pelotas, RS, Brasil, 2007. http://www.sosbai.com.br/recomendacoes.php accessed in March, 2011.

2. http://www.fao.org/rice2004/es/rice-us.htm accessed in March, 2011.

3. Alister, C.; Kogan, M.; Crop Prot. 2006, 25, 202.
4. http://www.arroz.agr.br/site/interarroz/zip/ia0610pt.pdf acessed in August, 2010.

5. http://www.conab.gov.br/OlalaCMS/uploads/arquivos/6a82d0 183ffcfc674c650b39955a8272.pdf acessed in March, 2011.

6. Luke, M. A.; Froberg, J. E.; Doose, G. M.; Masumoto, H. T.; J. AOAC Int. 1981, 64, 1187.

7. Ergonen, A. T.; Salacin, S.; Ozdemir, M. H.; J. Clin. Forensic Med. 2005, 12, 205.

8. Specht, W.; Tillkes, M.; Fresenius J. Anal. Chem. 1985, 322, 443.

9. Specht, W.; Pelz, S.; Gilsbach, W.; Fresenius J. Anal. Chem. 1985, 339, 376.

10. Sojo, L. E.; Brocke, A.; Fillion, J.; Price, S. M.; J. Chromatogr., A 1997, 788, 141.

11. Steinwandter, H.; Fresenius J. Anal. Chem. 1992, 343, 887.

12. Garcia, A. V.; Pradas, E. G.; Vidal, J. M.; Lopez, A. A.; J. Agric. Food Chem. 1991, 39, 2188.

13. Wilkowska, A.; Biziuk, M.; Food Chem. 2011, 125, 803.

14. Anastassiades, M.; Lehotay, S. J.; Stajnbaher, D.; Schenck, F. J.; J. AOAC Int. 2003, 86, 412.

15. Lehotay, S. J.; De Kok, A.; Hiemstra, M.; J. AOAC Int. 2005, 88,595 .

16. Braga, J. W. B.; Bottoli, C. B. G.; Jardim, I. C. S. F.; Goicoechea, H. C.; Olivieri, A. C.; Poppi, R. J.; J. Chromatogr., A 2007, 1148, 200.

17. Sánchez-Martín, M. J.; Delgado-Pascual, R.; Iglesias-Jiménez, E.; Sánchez-Camazano, M.; J. Chromatogr., A 1996, 754, 295.

18. Kuster, M.; De Alda, M. L.; Barceló, D.; Mass Spectrom. Rev. 2006, 25, 900.

19. Ayano, E.; Kanazawa, H.; Ando, M.; Nishimura, T.; Anal. Chim. Acta 2004, 507, 211.

20. Geerdink, R. B.; Niessen, W. M. A.; Brinkman, U. A. T.; J. Chromatogr., A 2002, 970, 65.

21. Primel, E. G.; PhD Thesis, Universidade Federal de Santa Maria, Brazil, 2003. Primel, E. G.; Zanella, R.; Kurz, M. H. S.; Gonçalves, F. F.; Machado, S. O.; Marchezan, E.; Quim. Nova 2005, 28, 605 .

22. D'archivio, A. A.; Fanelli, M.; Mazzeo, P.; Ruggieri, F.; Talanta 2007, 71, 25.

23. Soares, L. V. In Curso Básico de Instrumentação para Analistas de Alimentos e Fármacos, Malone: Barueri, São Paulo, SP, Brasil, 2006, ch. 9, 10 and 15.

24. Prestes, O. D.; Friggi, C. A.; Adaime, M. B.; Zanella, R.; Quim. Nova 2009, 32, 1620.

25. Amato, G. W.; Elias, M. C.; Parboilização do Arroz, Editora Ricardo Lenz Ziede: Porto Alegre, RS, Brasil, 2005.

26. ANVISA - National Health Surveillance Agency, Brasil; Guia para Validação de Métodos Analíticos e Bioanalíticos, Resolução RE No. 899, 2003. http://www.asfconsultoria.com. br/normas/ANVISA5.pdf 
27. Pareja, L.; Césio, V.; Heinzen H.; Fernández-Alba, A. R.; TrAC, Trends Anal. Chem. 2010, 30, 270. doi: 10.1016/j. trac.2010.12.001.

28. Ribani, M.; Bottoli, C. B. G.; Collins, C. H.; Jardin, I. C. S. F.; Melo, L. F. C.; Quim. Nova 2004, 27, 771.

29. http://ec.europa.eu/food/plant/protection/resources/ qualcontrol_en.pdf accessed in March, 2011.

30. Lanças, F. M. In Validação de Métodos Cromatográficos de Análise, Editora RiMa: São Carlos, SP, Brasil, 2004.

31. Chandi, G. K.; Sogi, D. S.; J. Food Eng. 2007, 79, 592.

32. http://www.cnpaf.embrapa.br/parperfeito/arroz/farelo.htm accessed in March, 2011.
33. Fernández-Alba, A. R. In Chromatographic-Mass Spectrometry Food Analysis for Trace Determination of Pesticide Residues, Elsevier Science: Amsterdam, 2005.

34. Huber, L.; LC-GC Int. 1998, 11, 96.

35. http://ec.europa.eu/food/plant/protection/resources/ qualcontrol_en.pdf accessed in March, 2011.

36. http://www.codexalimentarius.net/mrls/pestdes/jsp/pest_q-s.jsp accessed in March, 2011.

37. http://www4.anvisa.gov.br/AGROSIA/asp/frm_dados_ ingrediente.asp?iVarAux = 1\&CodIn g=55 accessed in March, 2011.

Submitted: August 10, 2010

Published online: August 2, 2011 